\title{
Mathematical Modeling of Proton Exchange Membrane Fuel Cell
}

\author{
Dr. R.Seyezhai \\ Associate Professor \\ Department of EEE \\ SSN College of Engineering \\ Kalavakkam - 603110 \\ Tamilnadu, India
}

\author{
Dr.B.L.Mathur \\ Professor \\ Department of EEE \\ SSN College of Engineering \\ Kalavakkam - 603110 \\ Tamilnadu, India
}

\begin{abstract}
Fuel cells are electrochemical devices that convert the chemical energy of a reaction directly into electrical energy. Among the several types of fuel cell, Proton Exchange Membrane Fuel Cell (PEMFC) is a suitable choice for distributed energy sources. In this paper, a mathematical model of 750W PEMFC is developed. This model describes the behaviour of PEMFC under steady-state and transient conditions. Novel feature of this model is integration of all possible dynamic equations like dynamics of the charge equations like dynamics of the charge double layer capacitance, lumped fuel cell body dynamics and anode and cathode channel dynamics into a single model. The VI characteristic of PEMFC is obtained for different values of input parameters. The transient response of the PEMFC model over short and long-time periods is analyzed. Finally, the behaviour of the PEM fuel cell model under a resistive load is evaluated.
\end{abstract}

Keywords: PEMFC, Transient, Charge double layer

\section{INTRODUCTION}

Fuel cell is a high quality green energy source and it is gaining much attention because of its light weight, compact size, low maintenance, high efficiency and reliability. It serves as a potential source for electric power generation for standalone as well as for grid-tied applications. Compared with the other types of fuel cells, PEMFC shows promising results with its advantages such as low temperature, high power density, fast response, and zero emission if it is run with pure hydrogen, and it is suitable for use in portable power supply, vehicles, and residential and distributed power plants. In this paper, a mathematical model is proposed to simulate a PEMFC which accounts for the effects of different dynamic conditions in load current, pressure of input reactant gases, and fuel cell operating temperature.

The PEMFC model is simulated in MATLAB. The polarization curves (V-I characteristics of the PEMFC) are obtained for different values of input variables. The transient response of the PEMFC model over short and long-time periods is analyzed.

Section II gives the basic operation of PEMFC. Section III presents the modeling aspects of PEMFC. Section IV,V and VI presents the steady-state and transient response of PEMFC. SectionVII discusses about the polarization curves of PEMFC.

\section{BASIC OPERATION OF PEMFC}

PEMFC primarily consists of three components: a negatively charged electrode (cathode), a positively charged electrode (anode) and a solid polymer electrolyte membrane. Hydrated hydrogen gas is supplied at the anode and air is supplied at the cathode. At the anode, hydrogen gas in the presence of the platinum catalyst is ionized into positively charged hydrogen ions and negatively charged electrons. The reaction at the anode is:

$$
H_{2}=2 H^{+}+2 e^{-}
$$

The polymer membrane permits only positively charged hydrogen ions to flow from the anode to the cathode as shown in Figure 2.1.

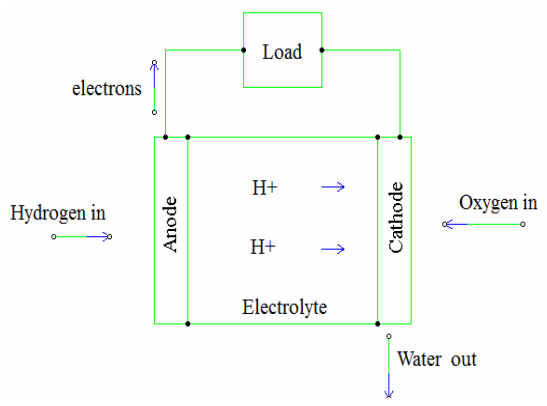

Fig.1 Basic operation of PEMFC

The PEMFC have a robust design and are relatively easy to build. A single fuel cell produces an open-circuit voltage of $0.7-1 \mathrm{~V}$. Several fuel cells are electrically connected in series forming a stack which provides a fairly large power at higher voltage and current levels.

\section{MODELING OF PEMFC}

Different models of PEM fuel cell are reported in the literature [2].This paper focuses on static and dynamic model of fuel cell system intended for power generation application (standalone/grid connected operation). The model is based on electrochemical equations that take into consideration the main operational parameters of fuel cell such as the operational electrical current, temperature and the transportation of gases. It depicts how the output voltage and power of fuel cell is affected due to changes in the load. The proposed model is simulated using MATLAB /Simulink and it is used to analyze the transient behaviour of the fuel cell. The VI characteristics of the PEM fuel cell are obtained for different values of input variables. An open circuit output voltage of the PEM fuel cell, voltage losses, formation of charge double layer in the PEM fuel cell, along with a mass balance and thermodynamic energy balance in the fuel cell system are modeled. Finally, the dynamic response of the fuel cell model over short and long time periods is analyzed. 


\section{STATIC MODEL OF PEMFC}

PEM fuel cells combine hydrogen and oxygen over a platinum catalyst to produce electrochemical energy with water as the byproduct. Fig.2. shows the I-V characteristics of a typical single cell operating at room temperature and normal air pressure. The variation of the individual cell voltage is found from the maximum cell voltage and the various voltage drops (losses). The output voltage of a single cell can be defined as

$$
\mathrm{V}_{\mathrm{fc}}=\mathrm{E}_{\text {Nernst }}-\mathrm{V}_{\text {act }}-\mathrm{V}_{\text {ohm }}-\mathrm{V}_{\text {conc }}
$$

In (2), ENerst represents the reversible voltage; Vact is the voltage drop due to the activation of the anode and cathode; Vohm is a measure of ohmic voltage drop associated with the conduction of the protons through the solid electrolyte and electrons through the internal electronic resistances; Vconc represents the voltage drop resulting from the concentration or mass transportation of the reacting gases [3]. ENerst represent the no-load voltage, while the sum of all the other terms gives the reduction of the useful voltage achievable at the cell terminals, when a certain load current is required. For $\mathrm{n}$ cells connected in

series and forming a stack, the voltage (Ecell), can be calculated by:

$$
E_{\text {cell }}=n \cdot V_{f c}
$$

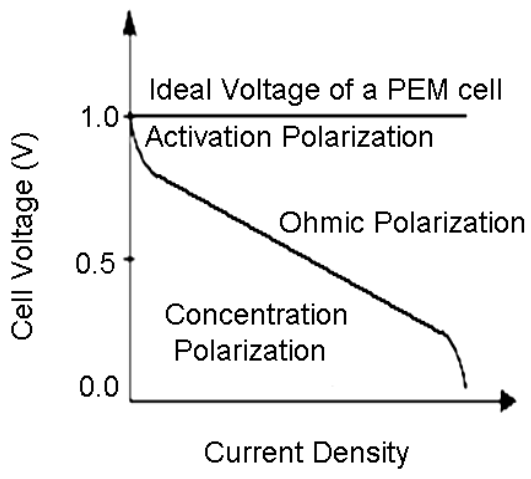

Fig .2 Ideal VI Characteristics of a Single PEMFC

From the above figure, the ideal voltage is the maximum voltage that each cell in the stack can produce at a given temperature with the partial pressure of the reactants and products known. It is calculated based on Gibbs free energy and it is given by

$$
\text { Enerst }=\frac{\Delta G}{2 F}+\frac{\Delta S}{2 F}\left(T-T_{r e f}\right)+\frac{R T}{2 F}\left[\ln \left(P_{H 2}\right)+\frac{1}{2} \ln \left(P_{o 2}\right)\right]
$$

where $\Delta \mathrm{G}$ is the change in the free Gibbs energy $(\mathrm{J} / \mathrm{mol}) ; \mathrm{F}$ is the constant of Faraday $(96.487 \mathrm{C}) ; \Delta \mathrm{S}$ is the change of the entropy $(\mathrm{J} / \mathrm{mol}) ; \mathrm{R}$ is the universal constant of the gases (8.314 $\mathrm{J} / \mathrm{K} \mathrm{mol}) ; \mathrm{PH} 2$ and $\mathrm{PO} 2$ while and are the partial pressures of hydrogen and oxygen (atm), respectively; variable $\mathrm{T}$ denotes the cell operation temperature $(\mathrm{K})$ and the Tref reference temperature. Several factors are responsible for the voltage drop in a fuel cell and they are referred as polarization. The losses originate from three sources: a) activation polarization b) ohmic polarization and c) concentration polarization [4]. Each of these is associated with a voltage drop and is dominant in a particular region of current density.

\section{Activation overvoltage}

The activation over voltage is the voltage drop due to the activation of anode and cathode .It can be calculated as:

$V_{a c t}=-\left[\xi_{1}+\xi_{2} \cdot T+\xi_{3} \cdot T \cdot \ln \left(C_{o 2}\right)+\xi_{4} \ln \left(I_{\text {stack }}\right)\right.$

where, $\mathrm{I}_{\text {stack }}$ is the cell operating current (A), and the $\xi \mathrm{i}$ 's represent parametric coefficients for each cell model, whose values are defined based on theoretical equations with kinetic, thermodynamic, and electrochemical foundations . $\mathrm{C}_{\mathrm{o} 2}$ is the concentration of oxygen in the catalytic interface of the cathode $\mathrm{mol} / \mathrm{cm}$, determined by

$$
\mathrm{C}_{\mathrm{o} 2}=\frac{\mathrm{P}_{\mathrm{o} 2}}{508 \cdot 10^{6} \cdot \mathrm{e}^{(-498 / \mathrm{T})}}
$$

\section{Ohmic voltage drop}

This loss occurs due to the electrical resistance of the electrodes, and the resistance to the flow of ions in the electrolyte .It is given by

$$
\mathrm{V}_{\text {ohmic }}=\mathrm{I}_{\text {stack }} \cdot\left(\mathrm{R}_{\mathrm{m}}+\mathrm{R}_{\mathrm{C}}\right)
$$

where $R c$ represents the resistance to the transfer of protons through the membrane, usually considered constant and $R_{m}$ is

$$
\mathrm{R}_{\mathrm{m}}=\frac{\rho_{\mathrm{M}} \cdot \mathrm{I}}{\mathrm{A}}
$$

$\rho_{M}$ is the specific resistivity of the membrane for the electron flow $(\mathrm{cm}), A$ is the cell active area $\mathrm{cm}$ and $l$ is the thickness of the membrane $(\mathrm{cm})$, which serves as the electrolyte of the cell.

\section{Concentration loss}

This is due to the change in concentration of reactants at the surface of the electrodes as the fuel is used causing reduction in the partial pressure of reactants, resulting in reduction in voltage given by

$$
\mathrm{V}_{\text {trans }}=-\frac{\mathrm{RT}}{\mathrm{n}} \cdot \mathrm{F} \cdot \ln \left(1-\frac{\mathrm{i}}{\mathrm{i}_{1}}\right)
$$

The consumption of more fuel reduces the concentrations of hydrogen and oxygen at various points in the PEM fuel cell gas channels and increases the concentrations of these reactants at the input of the stack. The static model of PEM fuel cell is shown in Fig.3.

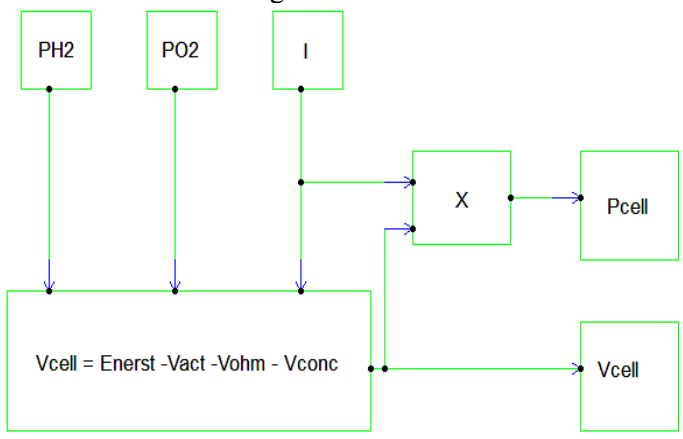

Fig.3. Static Model of PEMFC 


\section{Water Management in PEMFC}

The conduction of the hydrogen ions through the polymer membrane depends on the membrane humidity. The membrane dries out as the ohmic resistance increases. Hence, it is essential that the membrane remains humidified for an efficient operation of the fuel cell. Therefore, the hydrogen gas and air are passed through the humidifier before reaching the electrodes. The relative humidity at the anode and cathode of the PEM fuel cell is given by:

$$
\phi_{a}=\frac{\left(P_{H_{2} O}\right)^{i n}}{\left(P_{H_{2} O}{ }^{s a t}\right)}, \phi_{c}=\frac{\left(P_{H_{2} O}\right)^{i n}}{\left(P_{H_{2} O}{ }^{\text {sat }}\right)}
$$

\section{DYNAMIC MODEL OF PEMFC}

The dynamic model can predict the transient response of cell voltage, temperature of the cell, hydrogen/oxygen outflow rates, and cathode and anode channel temperatures/pressures under sudden change in load current. In this paper, a mathematical model is developed to simulate the transient phenomena using MATLAB. One unique feature of the proposed dynamic model is the inclusion of capacitance $\mathrm{C}$ to the voltage dynamics. In most of the existing dynamic models, such effect has not been taken into consideration. The charge double layer capacitance $\mathrm{C}$ is a function of the electrode and individual stack properties [4]. Whenever two different materials are in contact, there is a build up of charge transfer from one to the other. The voltage formed due to this charge double layer will take some time to respond to sudden change in the current. Therefore, in the PEM fuel cell, when the current is increased by sudden increase in the load, the output voltage shows an immediate drop due to the drop across the ohmic resistance of the cell, but then the voltage reaches its new value in an exponential manner, due to the capacitance of the charge double- layer. Taking into consideration the influence of this capacitance, the equivalent circuit for the PEM fuel cell is shown below:

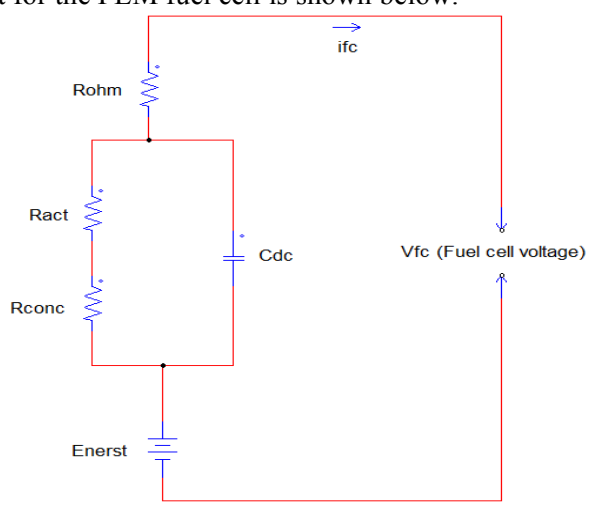

Fig.4. Equivalent electrical circuit of the dynamic model of PEMFC

where $R_{\text {ohm }}, R_{\text {act }}, R_{\text {con }}$ are respectively the representation for the ohmic, the activation and the concentration resistance; with $\mathrm{c}_{\mathrm{dc}}$ corresponding to the membrane capacitance due to the double layer effect. This effect is incorporated in the output voltage of the PEM fuel cell. Another improvement proposed in this modeling is the consideration of transient dynamics in anode/cathode channels and fuel cell body by applying non-steady state mass and energy principles on their respective control volumes. This feature enables us to predict the transient behaviour of molar flow rates, pressures and temperatures. The relationship between the molar flow of any gas through the valve and its partial pressure inside the channel can be expressed as

$\frac{\mathrm{q}_{\mathrm{H} 2}}{\mathrm{p}_{\mathrm{H} 2}}=\frac{\mathrm{K}_{\mathrm{an}}}{\sqrt{\mathrm{M}_{\mathrm{H} 2}}}=\mathrm{K}_{\mathrm{H} 2}$

For hydrogen molar flow, there are three significant factors: hydrogen input flow, hydrogen output flow and hydrogen flow [5] and the relationship among these factors can be expressed as

$$
\frac{d}{d t} p_{H 2}=\frac{R T}{V_{\text {an }}}\left(q^{i^{n}{ }_{H 2}}-q^{\text {out }}{ }_{H 2}-q^{r}{ }^{\mathrm{r} 2}\right)
$$

The relation between the partial pressure and the input flow rate of the fuel is given by

$$
\begin{aligned}
& \mathrm{p}_{\mathrm{H} 2}=\frac{1 / \mathrm{k}_{\mathrm{H} 2}}{1+\tau_{\mathrm{H} 2} \mathrm{~S}}\left(\mathrm{q}^{\mathrm{in}}{ }_{\mathrm{H} 2}-2 \mathrm{k}_{\mathrm{r}} \mathrm{I}\right) \\
& \mathrm{p}_{\mathrm{o} 2}=\frac{1 / \mathrm{k}_{\mathrm{o} 2}}{1+\tau_{\mathrm{o} 2} \mathrm{~S}}\left(\mathrm{q}^{\mathrm{in}}{ }_{\mathrm{o} 2}-\mathrm{k}_{\mathrm{r}} \mathrm{I}\right)
\end{aligned}
$$

where the constant $\mathrm{K}_{\mathrm{r}}$ is defined by the relation between the rate of reactant hydrogen and fuel cell current

$$
q_{H 2}^{r}=\frac{N . I .}{2 F U}=2 K r . I
$$

The partial pressure of water can be calculated using the same expression for partial pressure of hydrogen and oxygen [6]. Using equations (10) - (15), the dynamic model of FC is simulated using MATLAB and the block diagram is shown in Fig.5.

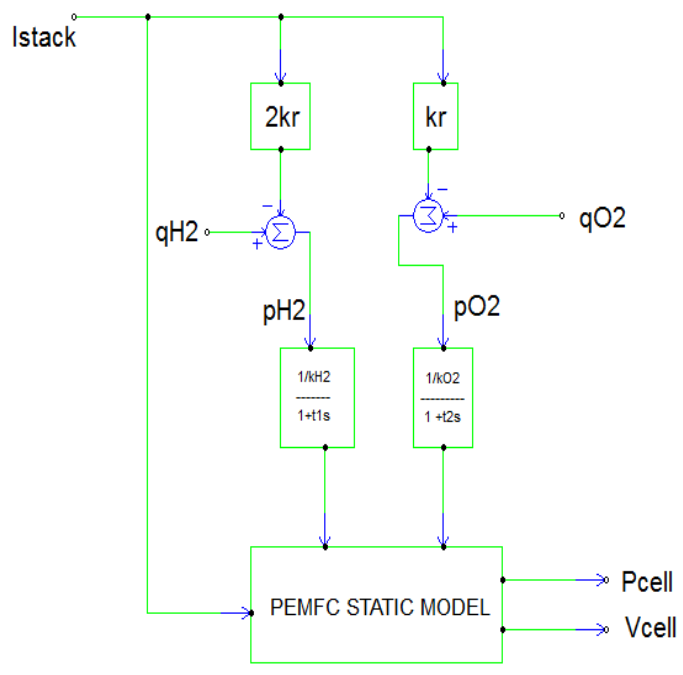

Fig.5.Dynamic Model of PEMFC

The unique feature of the dynamic model discussed in this paper is the integration of all possible dynamic equations by including dynamics of the charge double layer capacitance, lumped fuel cell body dynamics, and anode and cathode 
channel dynamics. This enables us to capture the transients in cell voltage, temperature of the cell, hydrogen/oxygen input and out flow rates and cathode and anode channel temperatures/ pressures under sudden change in load current.

\section{SIMULATION RESULTS}

To obtain the V-I characteristics of the PEM fuel cell, the model is simulated using MATLAB for the following values of input variables: $\mathrm{P}_{\mathrm{H} 2}$ (anode pressure) $=2 \mathrm{~atm}, \mathrm{P}_{\mathrm{O} 2}$ (cathode pressure $)=1 \mathrm{~atm}, \mathrm{~T}($ temperature of the cell $)=323 \mathrm{~K}$. The simulated V-I characteristics of a single PEM fuel cell are shown in Fig.6 which depicts the various polarization losses. The power versus current density curve shows the maximum peak power supplied by the fuel cell is $750 \mathrm{~W}$.
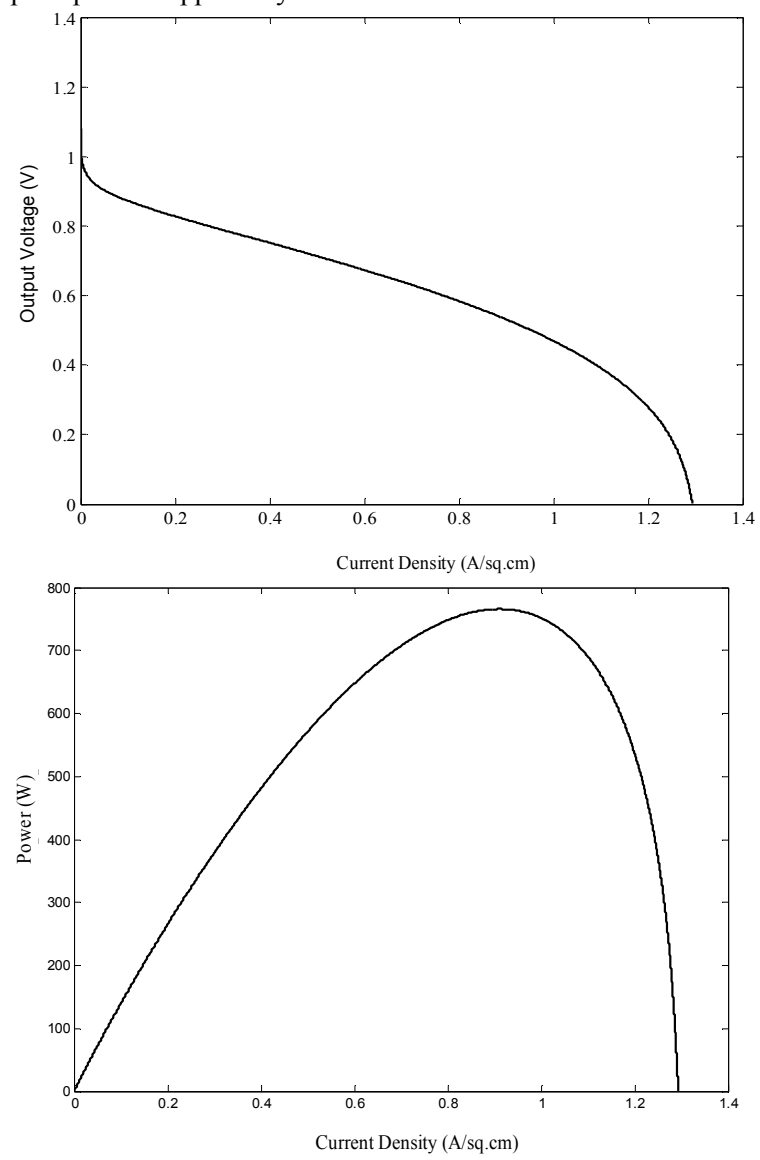

Fig.6.Simulated Polarization curve for a PEMFC

\section{POLARIZATION CURVES OF PEM FUEL CELL}

The PEM fuel cell model is subjected to different values of input variables in order to study their effect on the V-I characteristics, the output voltage of the PEM fuel cell and polarization losses. Figs.7\&8. shows the V-I characteristics of the fuel cell model for increasing values of anode and cathode pressure.

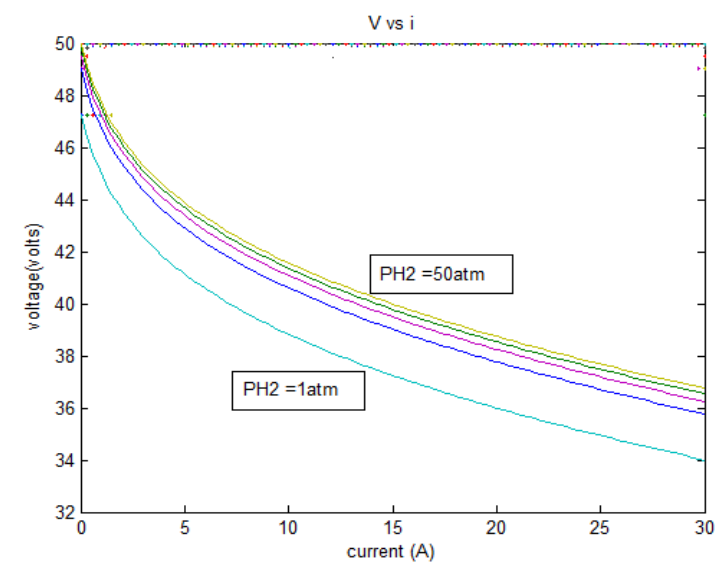

Fig.7. Characteristics of the PEMFC model for increasing value of anode pressure.

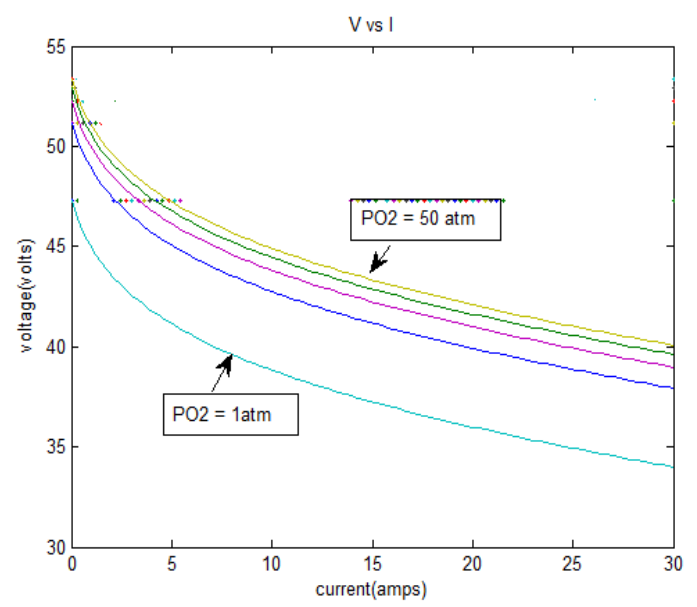

Fig.8. Characteristics of the PEMFC model for increasing value of cathode pressure

As the partial pressure of hydrogen/oxygen increases, the output voltage of the fuel cell increases. This increase in the output voltage decreases the voltage losses in the cell. Therefore, for higher values of anode/cathode pressure, the voltage losses are reduced in the PEM fuel cell $[7,8$,$] .$

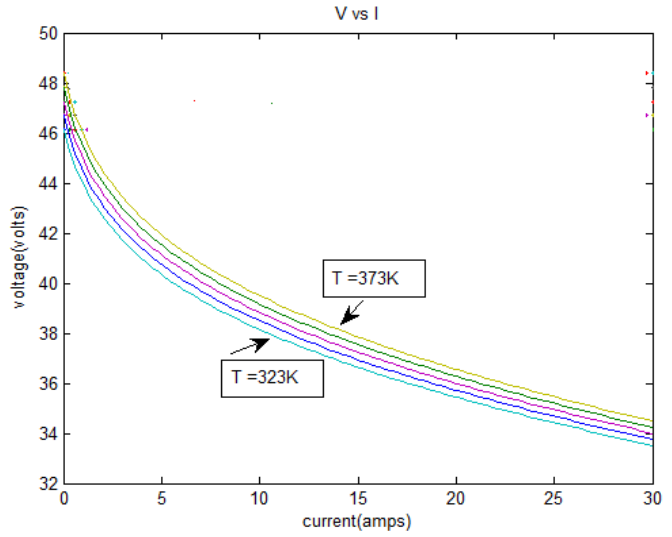

Fig.9. Characteristics of the PEMFC model for increasing values of $\mathrm{FC}$ temperature 
Fig.9 shows the temperature dependent $I-V$ characteristics of PEM fuel cell from 308 to $316 \mathrm{~K}$. As the temperature increases, the water removal is easier. The effects are considerably high at the range of the higher cell current, where more water is produced. PEMFCs show increase in voltage till a point and suddenly voltage drops with further increase in temperature. The nernst voltage, the activation overvoltage, the ohmic voltage and the concentration overvoltage of the simulated fuel cell is shown in Fig.10.

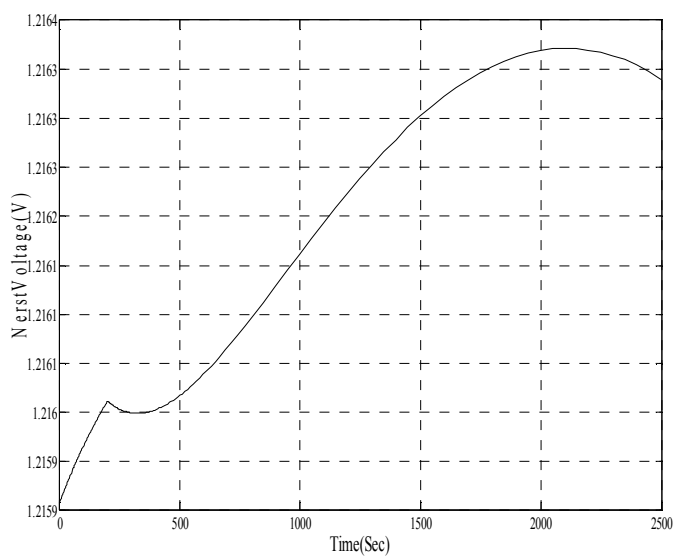

Fig.10.Nerst voltage curve of PEMFC.

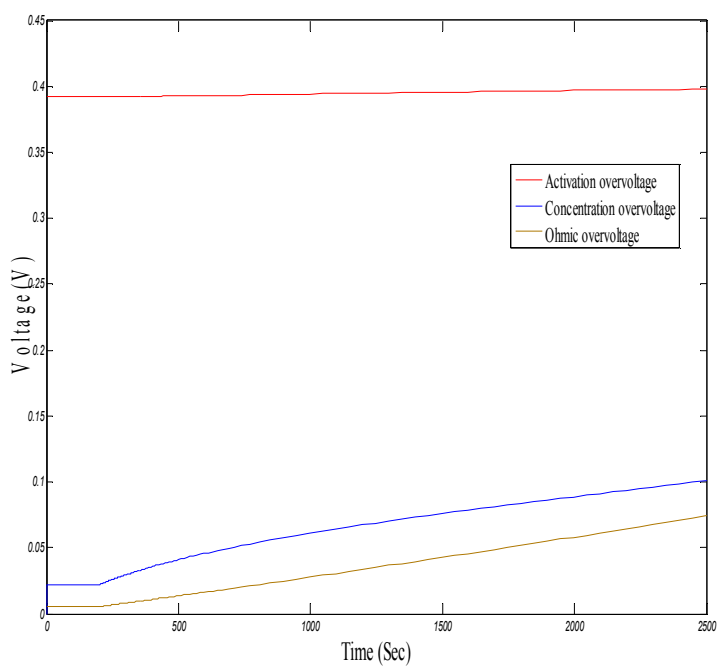

Fig.11. Curves of over voltage in a PEMFC

The transient response of the PEM fuel cell is shown in Figs. $12 \& 13$. It can be seen that as the load is increased, the output voltage of the PEM fuel cell drops, and vice-versa. However, the output voltage does not reach a new value instantly. As the load is increased, the voltage drops to a certain value immediately but from there it reaches to its new value in an exponential manner. This is due to the capacitance of the charge double layer formed at the surface of the cathode $[9,10]$.

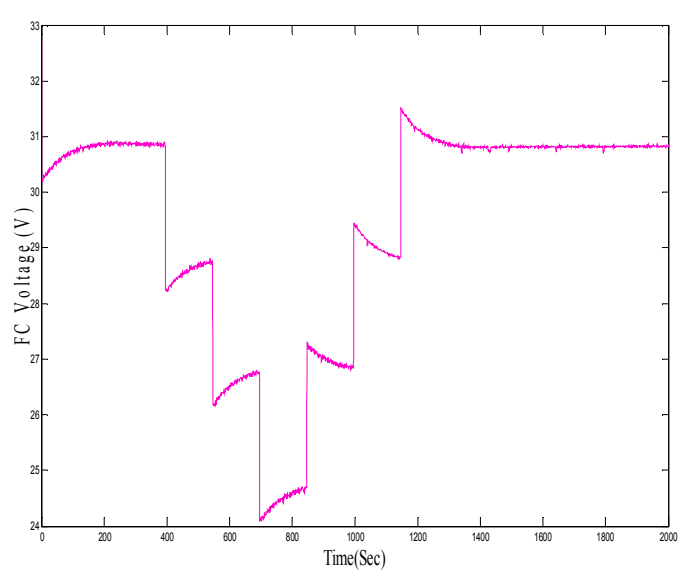

Fig.12.Transient response of FC voltage

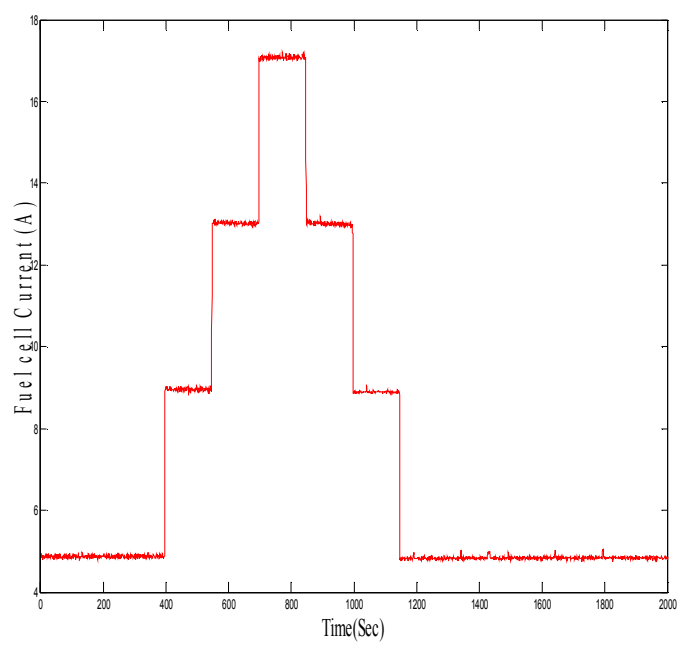

Fig.13 Transient response of FC Current

Simulation results presented above clearly indicate the transients expected in a PEMFC. The results have shown that the model is capable of predicting transient behavior in voltage, current and temperature profiles. This will be useful in developing a control strategy for the fuel cell and when investigating highly transient processes such as fuel cell startup on a vehicle $[11,12]$.

\section{CONCLUSIONS}

In this paper, a mathematical model is proposed to simulate the steady -state and transient phenomena in a PEMFC system. The V-I characteristics of the fuel cell are obtained for different values of the input parameters and it is found that by operating the fuel cell at the higher values of input variables, voltage losses can be reduced. The complete set of equations were developed to characterize the effects of charge double layer capacitance, the dynamics of flow and pressure in the anode and cathode channels and mass/heat transfer transient features in the fuel cell body. The simulation results obtained using the proposed model lays a foundation in designing controllers for fuel cell based power generation applications. 


\section{ACKNOWLEDGMENTS}

The authors wish to thank the management of SSN college of Engineering, Chennai for providing all the computational facilities to carry out this work.

\section{REFERENCES}

[1] Ali, D.M. , "A simplified dynamic simulation model for a standalone Polymer Electrolyte Membrane (PEM ) fuel cell stack', Proc.of the First International Middle -East Conference on Power System, MEPCON 2008, pp. 480 485 .

[2] Correa,J.M., Farret,F.A., Canha,L.N., Simoes,M.G. , “An Electrochemical based fuel -cell model suitable for electrical engineering automation approach ", IEEE Trans. on Industrial Electronics, Volume 51, Issue 5, 2004, pp.1103-1112.

[3] Caisheng Wang, Nehrir, M.H., Shaw S.R., "Dynamic Models and Model Validation for PEM Fuel Cells Using Electrical Circuits”, IEEE Transactions on Energy Conversion, 2005, Vol. 20, Issue 2, pp. 442-451.

[4] Friede W., Rael S., Davat B. ," Mathematical model and characterization of the transient behavior of a PEM fuel cell", IEEE Transactions on Power Electronics,2004, Vol. 19, Issue 5, pp. 1234-1241.

[5] Georgis,D. Papathanassiou ,S. Mania,S., "Modeling and control of a small scale grid -connected PEM fuel cell system", , in the Proc.of the $36^{\text {th }}$ IEEE Power Electronics Specialists Conference,PESC'05, pp. 1614 1620 .
[6] Hatziadoniu .C.J. , Lobo, A. A., Pourboghrat, .F., Daneshdoost, M. , "A simplified dynamic model of grid connected fuel cell generators", IEEE Trans. On Power delivery, 2002,Vol.17, pp.467 -473.

[7] Haubrock J., Heideck G., Styczynski Z. ,"Dynamic Investigation on Proton Exchange Membrane fuel cell systems", IEEE Power Engineering Society general meeting, 2007,pp. 1- 6 .

[8] Mammar.K., Chaker.A., "Fuzzy logic based control of power of PEM fuel cell system for residential application", Leonardo Journal of Sciences,2009, Issue 14, pp. $147-166$.

[9] Pasricha.S. Keppler.M., Shaw.S.R., and Nehrir.M.H. , "Comparison and identification of static electrical terminal fuel cell models", IEEE Trans. on Energy Conversion,2007, vol.22, pp.746 -754.

[10] Saha.A.K.Chowdhury.S.,Song.Y.H. , , "Software simulation of PEM fuel cell system for dynamic performance analysis", IEEE International Conference, 2007,pp.758 -762.

[11] Wang.Y, Wang .C., "Transient analysis of polymer electrolyte fuel cells", Journal of power sources,2005, pp.1307 -1315

[12] Wingelaar .J.P.H,. Duarte .J.L., Hendrix.M.A.M. , "PEM fuel cell model representing steady-state, small-signal and large-signal characteristics", Journal of power sources, 2007, pp.754 -762. 